\title{
HOGYAN GONDOLKODNAK A PEDAGÓGUSOK SAJÁT KOMPETENCIÁIK SZÍNVONALÁRÓL ÉS FEJLŐDÉSI FOLYAMATÁRÓL? KOTSCHY BEÁTA
}

ny. föiskolai tanár beata@kotschy.hu

\begin{tabular}{l}
\hline Az alprojekt részét képezi az „Együttmüködés az észak-magyarországi pedagógusképzés \\
megújitásáért” címü projektnek, amelyen belül a szakmai tartalom gazdagitásával kivánja \\
a hazai pedagógusképzés minöségének fejlesztését segiteni. Vállalt célja a pedagógusok \\
gyakorlati tudásának, a pedagógiai kompetenciákról kialakitott nézeteiknek, az egyes \\
kompetenciák fejlettségének és a szakmai fejlödés folyamatánakfeltárása, s ezzel a képzés és \\
továbbképzés tartalmi és módszertani fejlesztésének megalapozása. Jelen tanulmány a \\
pedagóguskompetenciák fejlödési/fejlesztési folyamatát vizsgálja három területen, a \\
gyakorlati tapasztalatok spontán hatását, az elégedettségböl/elégedetlenségböl fakadó belsö \\
késztetések motiváló erejét és a külső elvárásokat, mint a fejlödéslehetséges inditékait. \\
\hline
\end{tabular}

Kutatásunk fontos célja volt az egyes kompetenciák bemutatása mellett a kompetenciák általános fejlődési folyamatának és a fejlődést segítő feltételeknek feltárása volt.

A pedagógus életpályamodell kidolgozásakor az egyik szakmai kihívást az jelentette, hogy meg tudjuk-e határozni a különböző szintek elérésének kritériumait a szakmai fejlettség szempontjából. Különösen fontos volt meghatározni a kompetenciák fejlettségével szemben támasztott követelményeket a pedagógus 1 . és 2. szintek esetében, ahol a minősítés eredménye kizárólagosan a 8 kompetencia fejlettségének vizsgálatán alapul.

A vizsgálat során abból a feltevésből indultunk ki, hogy a kompetenciaszintek (sztenderdek) meghatározásánál a tudás, képességek és attitűdök fejlettségét együttesen és komplex módon kell vizsgálni, s hogy ezek a komponensek időben eltérő módon és ütemben fejlődnek, erősödnek. Az időbeni eltolódásokat magyarázza:

- A kompetenciák három komponensének eltérő ütemü a változása. Míg az ismeretek elsajátítása meghatározóan a képzés során történik, a képességek döntő többsége a gyakorlati pedagógiai munka során alakulhat csak. Sajátos kategóriát jelent az attitüdök formálódása, amelynek fontos terepe a képzési időszak, de stabillá válásuk csak a valós pedagógiai helyzetek megélése után képzelhető el, s erre a „szembesítő” folyamatra általában nem a folyamatos, egy irányba ható fejlődés jellemző. 
- A különböző tanulási körülmények (a képzőintézménytől a gyakorlóhelyekig, majd a munkahelyeken keresztül a különböző továbbképzésekig) más-más tanulási környezetet biztosítanak, és eltérő elvárásokat fogalmaznak meg az egyén számára az egyes kompetenciák fejlődése terén.

- Az eltérő egyéni szakmai fejlődési utak mellett az egyéni képességek szintén lassíthatják, vagy gyorsíthatják a fejlődés folyamatát.

Az interjúk során arra kértük a pedagógusokat, hogy gondolják végig, hogyan, mikor, milyen hatásra fejlődtek szakmai képességeik, tudásuk, attitüdjeik. Természetesnek vettük, hogy a hosszabb idő óta pályán lévők emlékezetében már nem él olyan tisztán ez a hatásrendszer, ugyanakkor elmondásaik rávilágítanak a szakmai tudatosságuk színvonalára.

Alapvetően a fejlődés belső rugójaként három területet kívántunk feltárni, a gyakorlat hátására spontán bekövezkező változásokat, a saját munkával való elégedettség-elégedetlenség dimenzióját, ehhez szorosan kapcsolódva a belső késztetéseket, s végül a külső motívumokat.

\section{A tanítási tapasztalatok hatására bekövetkező változások}

A spontán szakmai fejlődés sajátosságainak bemutatására a pedagógiai tervezés kompetenciájára vonatkozó adatok tüntek alkalmasnak, mivel olyan általános fejlödési tendenciákat mutatnak, amelyek a többi kompetencia esetében is relevánsak. Ezt egészítettük ki néhány, az adott kompetenciára jellemző konkrét adattal.

1. táblázat: A tapasztalatok hatására bekövetkezö pozitív változások összefoglalása

\begin{tabular}{|l|l|}
\hline \multicolumn{1}{|c|}{ Kezdö években } & \multicolumn{1}{|c|}{ Jelenleg } \\
\hline $\begin{array}{l}\text { A képzés során kialakított sémákhoz } \\
\text { való ragaszkodás }\end{array}$ & Önálóság növekedése \\
\hline A megtanultakhoz való ragaszkodás & Szelektálás képessége \\
\hline Aprólékos részletezés & Lényegkiemelés \\
\hline Minták másolása, adaptálása & Tudatosság növelése \\
\hline Tartalomcentrikusság & $\begin{array}{l}\text { Munkaformák, eszközök elötérbe } \\
\text { kerülése }\end{array}$ \\
\hline
\end{tabular}




\begin{tabular}{|l|l|}
\hline $\begin{array}{l}\text { Részletekre töredezettség (tanórában } \\
\text { való gondolkodás) }\end{array}$ & $\begin{array}{l}\text { Nagyobb összefüggésekben és } \\
\text { egységekben való gondolkodás }\end{array}$ \\
\hline Bonyolult gondolkodás & A döntések egyszerüsödése \\
\hline Szorongás, bizonytalanság & Céltudatosság, magabiztosság \\
\hline Ragaszkodás az elózetes tervhez & Rugalmas megvalósítás \\
\hline $\begin{array}{l}\text { Tananyag tanításának tervezése } \\
\text { (pedagógus tevékenysége) }\end{array}$ & $\begin{array}{l}\text { A tanulók sajátosságainak } \\
\text { figyelembevétele (6 fó említi) }\end{array}$ \\
\hline Egyféle megoldás tervezése & $\begin{array}{l}\text { Variációkban való gondolkodás, a } \\
\text { válogatás lehetósége (1 fö válasza) }\end{array}$ \\
\hline
\end{tabular}

A 4. komptencia fejlődését a nyitottabbá, türelmesebbé válás, az okfeltáró attitüd kialakulása, a tanulói megismerés módszereinek gazdagodása jelenti. A 6.kompetecia az egyéni képességek figyelembe vételét, a kevésbé szigorú ,s talán reálisabb értékelést, a fejlesztést előtérbe helyező attitüd erősödését mutatja. A kommunikációs képesség az évek során 3 területen fejlődött nagyobb mértékben, a kommunikációs ügyesség terén (például egyszerübb, rövid és érthető utasítások, a mondatok egyértelmübb tartalma stb.), a szakmai kommunikációban (például magyarázatok minősége), $\mathrm{s}$ végül a magabiztosabb véleménynyilvánításban.

A pozitív változások az elözetes feltételezéseknek megfelelöen a tudatosság, a nagyobb összefüggésekben és távlatokban való gondolkodás, gazdagabb módszertani repertoár, a döntéshozatal magabiztossága terén jelentkeztek. A fejlödés másik forrása a tanulók mélyebb megismerése, a közvetlen személyes tapasztalatok gazdagodása. Ezek a példák a tapasztalatok hatására szinte spontán érésként értelmezhetők. Nem is minden esetben váltak tudatossá, s ezért tudtak csak nagyon nehezen beszélni ezekről a folyamatokról.

Érdemes figyelembe venni azokat az információkat is, amelyek arról szólnak, hogy a pályán eltöltött éveknek negatív hatása is van, példaként ismét a felkészülésre vonatkozóan:

- „A kezdeti alaposság megkopik.”

- "Már tudom, mit kell tanítanom, nincs szükségem alapos tervezésre.”

- "A sok tapasztalat hatására automatizmussá válik."

- „Ami bevált, továbbviszem.”

- „Sok mindent készen lehet kapni (tanmenet feladatbank, központi felmérök), abból válogatok."

- „Kiégünk a gyerekek miatt.” 


\section{Az elégedettség/elégedetlenség, mint a fejlődés belső motívációja}

A pedagógusok önmaguk szakmai szinvonalával való elégedettségét azért vizsgáltuk. mert feltételeztük, hogy a túlzott elégedettség kevéssé motiválja a kollégákat a folyamatos önképzésre, hiányosságaik tudatos pótlására. Figyelmbe vettük azt is, hogy az önértékelés általában a vártnál sokkal pozitívabb az elénk tárt kép, s nem az őszintén átgondolt szintet mutatja, hanem a külső értékelő számára „szépített“ egy kicsit.

Az egyes kompetenciák vizsgálata során a direkt kérdésekre kapott válaszok alapján 80-90\%-a a megkérdezetteknek teljesen elégedett. Ebbe a csoportba tartoznak a kezdők éppúgy, mint az a kolléga, aki nem is rendelkezik a tanított tárgyához megfelelő szakképzettséggel. (Természetesen 1-1 válasz alapján semmiféle következtetést nem szabad levonni, de az érdekesség kedvéért érdemes megemlíteni.)

Az adatok feldolgozása során készítettünk egy, a pedagógus elégedettségére vonatkozó összetett mutatót is. Ez a teljes interjú összbenyomására épült. Az elégedettség értékelése 7 jegyủ skálán történt.

2.táblázat: A pedagógusok elégedettsége saját kompetenciáikkal

\begin{tabular}{|c|c|c|}
\hline \multicolumn{1}{|c|}{ Kompetencia } & Átlag & Szórás \\
\hline 1. kompetencia & $5,34(6)$ & 1,60 \\
\hline $2 . \quad$ kompetencia & $5,44(5)$ & 1,71 \\
\hline 3. kompetencia & $4,16(9)$ & 1,38 \\
\hline 4. kompetencia & $5,5(4)$ & 0,78 \\
\hline 5. kompetencia & $4,65(7)$ & 1,56 \\
\hline $6 . \quad$ kompetencia & $5,58(3)$ & 0,88 \\
\hline $7 . \quad$ kompetencia & $6,19(1)$ & 1,79 \\
\hline 8. kompetencia & $6,08(2)$ & 1,18 \\
\hline 9. kompetencia & $4,22(8)$ & 1,12 \\
\hline
\end{tabular}

Az átlageredmények azt mutatják, hogy mind a 9 területen a közepesnél valamivel jobbra értékelhetők a kompetenciák. A fó pedagógiai feladatok ellátásában (a tanulás támogatása és a közösségfejlesztés) találhatók nagyobb bizonytalanságok, míg a kommunikáció és együttmüködés, illetve a szakmai fejlődésükért való elkötelezettség terén érzik magukat legerősebbnek a pedagógusok.

Ugyanakkor a magas szórásértékek ezek iránt is kétséget ébresztenek. Kiemelhető az értékelési kompetencia előkelő helye (és aránylag kis szórása), amit az interjú szövegei kevéssé támasztanak alá. A biztonságérzet alapját elsősorban a központi értékelés folyamata képezi. Erre mutat az is, hogy az értékelés minősítő 
funkciója a meghatározó a napi tanítási folyamatban is. A belső motivácó terén kevés említés történt arra, hogy a pedagógus saját konkrét problémáinak jobb megoldására törekszik.

Összefoglalásként elmondható, hogy a megkérdezettek válaszai alapján nem fogalmazható meg, hogy melyek azok a konkrét kompetenciák, kompetenciaelemek, amelyek fejlesztésének szükségességét érzik. Általánosságban mondják csak, hogy elkötelezettek a folyamatos szakmai fejlödésük mellett, de egyéni megközelítésekkel, személyes igényekkel, elképzelésekkel nem találkozhattunk az interjúkban.

\section{Külső motívumok szerepe a fejlődésben}

A kollégák nagyon konkrétan megfogalmazták a külső hatásokat, amelyek szükségessé teszik a változásokat/változtatásokat. Ilyenek például a megváltozott társadalmi elvárások, az új tantervek, tankönyvek, a technikai fejlődés által megjelenő új lehetőségek.

Hasonlóképp külsőnek tekinthetők a továbbképzések motiváló, gazdagító hatásai. Ezek elsősorban a módszerek, munkaformák és taneszközök, IKT eszközök használata terén jelentettek eredményes fejlődést. Sokan említették az ellenőrzésértékelés új megközelítését is, de öszintén bevallva, hogy például a fejlesztőtámogató értékelés terén még nagyon távol állnak a korszerü pedagógiai elvárásoktól. A válaszok szövegének elemzése azt igazolja, hogy egyes továbbképzéseknek igen nagy hatása van arra, amit tesznek, de egyáltalán nem tudatosítják azt, hogy miért teszik. Közelebb áll az új tudás a „kapott receptek” (néha adaptív) megvalósításához, mint a tudatosan átgondolt célszerü alkalmazáshoz. Megdöbbentő adat, hogy a megkérdezettek $90 \%$-a részt vett különböző szintü tantervkészítési/fejlesztési munkálatokban, s egyetlen egy sem jelezte közülük, hogy ez hatással lett volna a tervezési kompetenciájára.

Ugyanakkor megfogalmazták azt is, hogy a leghatékonyabb motiváció a szakmai fejlödésre, az önképzésre a különbözö feladatokban, tevékenységekben, illetve fejlesztésekben való aktív részvétel. Ezt ugyan nem igazolja a tantervi munkálatokban való részvétel hatékonysága, de mint a napi munka folyamatából való kiemelkedés, más kollégákkal való együttmüködés mégis megindítja a fejlődés iránti igény kialakulását.

A kompetenciák szintjében fentebb bemutatott változás az esetek többségében nem tudatos tanulás, hanem spontán „érési“ folyamat eredménye. Jelenleg a továbbképzéseken való részvétel az általános lehetőség a fejlődésre. Ezeknek igen nagy hatása van arra, amit a pedagógusok tesznek, de egyáltalán nem tudatosítják azt, hogy miért teszik. A jövőben nagyobb hangsúlyt kell fektetni az önképzés, egymástól való tanulás, az intézményi szintủ fejlesztési folyamatok általánossá tételére, $\mathrm{s}$ ezeknek továbbképzésként való elismerésére. 
A fejlődésben megmutatkozó egyenetlenségek, eltolódások, hangsúlybeli különbségek arra hívják fel a figyelmet, hogy ha a tanári szakmai fejlődés általános folyamatáról és szintjeiröl beszélünk, inkább irányvonalakban mint törvényszerüségekben gondolkodunk.

Az egyes konkrét szintek kritériumai mellett rendkívül fontos, hogy magát a fejlödést folyamatként értelmezzük, s ennek motiváló eszközeként a folyamatos értékelés gyakorlatát is alapvető feltételként fogalmazzuk meg (jól müködő minőségbiztosítás, rövidebb távú például éves egyéni fejlődési terv). Az eltérő fejlődés sajátosságait elsősorban a fejlődés támogatása során kell figyelembe venni, a folyamat menetében kell nyomon követni, a szintek értékelésénél viszont a kompetencia egészének a fejlettségét kell megítélni. 